\title{
Possible Role of GnIH as a Mediator between Adiposity and Impaired Testicular Function
}

\section{OPEN ACCESS}

Edited by:

Ishwar Parhar,

Monash University Malaysia, Malaysia

Reviewed by:

Tatsushi Onaka,

Jichi Medical University, Japan

Suraj Unniappan,

University of Saskatchewan, Canada

${ }^{*}$ Correspondence:

Amitabh Krishna

akrishna_ak@yahoo.co.in

Specialty section:

This article was submitted to Experimental Endocrinology, a section of the journal

Frontiers in Endocrinology

Received: 30 July 2015 Accepted: 15 January 2016 Published: 03 February 2016

Citation:

Anjum S, Krishna A and Tsutsui K (2016) Possible Role of GnIH as a Mediator between Adiposity and Impaired Testicular Function.

Front. Endocrinol. 7:6.

doi: 10.3389/fendo.2016.00006

\author{
Shabana Anjum ${ }^{1}$, Amitabh Krishna ${ }^{1 *}$ and Kazuyoshi Tsutsui ${ }^{2}$ \\ ${ }^{1}$ Department of Zoology, Banaras Hindu University, Varanasi, India, ${ }^{2}$ Department of Biology, Waseda University, Tokyo, Japan
}

The aim of the present study was to evaluate the roles of gonadotropin-inhibitory hormone $(\mathrm{GnlH})$ as an endocrine link between increasing adiposity and impaired testicular function in mice. To achieve this, the effect of $\mathrm{GnlH}$ on changes in nutrients uptake and hormonal synthesis/action in the adipose tissue and testis was investigated simultaneously by in vivo study and separately by in vitro study. Mice were treated in vivo with different doses of $\mathrm{GnIH}$ for 8 days. In the in vitro study, adipose tissue and testes of mice were cultured with different doses of $\mathrm{GnlH}$ with or without insulin or $\mathrm{LH}$ for $24 \mathrm{~h}$ at $37^{\circ} \mathrm{C}$. The $\mathrm{GnlH}$ treatment in vivo showed increased food intake, upregulation of glucose transporter 4 (GLUT4), and increased uptake of triglycerides (TGs) in the adipose tissue. These changes may be responsible for increased accumulation of fat in white adipose tissue, resulting in increase in the body mass. Contrary to the adipose tissue, treatment with $\mathrm{GnIH}$ both in vivo and in vitro showed decreased uptake of glucose by downregulation of glucose transporter 8 (GLUT8) expressions in the testis, which in turn resulted in the decreased synthesis of testosterone. The GnlH treatment in vivo also showed the decreased expression of insulin receptor protein in the testis, which may also be responsible for the decreased testicular activity in the mice. These findings thus suggest that $\mathrm{GnlH}$ increases the uptake of glucose and TGs in the adipose tissue, resulting in increased accumulation of fat, whereas simultaneously in the testis, GnlH suppressed the GLUT8-mediated glucose uptake, which in turn may be responsible for decreased testosterone synthesis. This study thus demonstrates $\mathrm{GnIH}$ as mediator of increasing adiposity and impaired testicular function in mice.

Keywords: GnIH, adipose tissue, testis, GLUT4, GLUT8

\section{INTRODUCTION}

Nutrition has a significant impact on reproductive processes, including steroidogenesis, gametogenesis, early embryonic development, etc. $(1,2)$. This association is because reproductive activities are energetically expensive, and the brain modulates the reproductive processes according to nutritional availability $(3,4)$. The reproductive tissues appears to have a number of "nutrient sensing" mechanisms that may link nutrient status to the reproductive system. Glucose is a very important mediator of nutritional effects on reproduction. Blood concentrations are inversely correlated to energy intake (5). Glucose is transported by the family of facilitative glucose transporters (GLUTs), which are 
involved in hypothalamic regulation $(6,7)$. Glucose also plays a major role in providing metabolic substrates to germ cells in the gonads $(8,9)$. GLUTs in cells act as glucose sensors. Glucose availability influences lutienizing hormone (LH) secretion through gonadotropin-releasing hormone $(\mathrm{GnRH})$ system (10). Insulin is a modulator of the metabolic stimulus and plays crucial roles in the relationship between changes in nutritional levels and reproduction (11). The anabolic actions of insulin on peripheral tissues are well established and plasma insulin also serves as a signal of body fat content to the central nervous system (12). Insulin also amplifies the lipogenesis in adipose tissue (13). Glucose is made available in the body by insulin, which helps to lower the level of circulating glucose by promoting its uptake either in adipose tissue or muscle cells through GLUT4 (14). In the gonads, glucose is essential for maintenance of spermatogenesis in vivo $(15,16)$. The isoforms of GLUTs are expressed in the testis (17). GLUT8 appears to be one of the main GLUTs in the testis (18). Furthermore, it has been demonstrated that adequate amount of GLUT is required for proper testicular activity (18). Insulin has a direct effect at the testis level (16). Insulin receptors (IR) are expressed in both somatic cells, such as Leydig, Sertoli, and peritubular cells, and germ cells in the testis of various vertebrate species (19). IR signal through the IR substrate proteins (IRS) $(20,21)$ plays a role in regulating fertility under normal fed conditions.

Adipose tissue is the main organ in the body that provides a storage site for triglycerides (TGs) and deals with energy homeostasis. Serum glucose is taken up and stored as fatty acid via lipogenesis in adipocytes, whereas the fall in glucose levels stimulates lipolysis, leading to release of TGs/fatty acid. Mature adipocytes synthesize and secrete numerous hormones called adipokines, which are involved in overall energy homeostasis and also modulate reproductive activities. Recent studies have shown a negative relationship between adiposity and testicular function $(22,23)$. Although a more recent study suggested a strong association between metabolic disorders and infertility (24), the factors mediating the influence of nutrition on reproduction are currently not clearly known and require detailed investigation.

The neural elements within the brain that control nutritional function and those that control reproduction are interconnected. Thus, studies are required to understand how the neural system that affects food intake may impact on reproductive function. As a generalization, neuropeptides that stimulate reproduction inhibit food intake and vice versa. Central (neuroendocrine) regulation of both reproduction and nutritional function provides a meas whereby surplus energy or energy deficit can be perceived, and accordingly, food intake and energy expenditure can be modulated (25). In 2000, a novel hypothalamic neuropeptide that actively inhibits gonadotropin release was discovered in quail and termed gonadotropin-inhibitory hormone (GnIH) (26). GnIH has a C-terminal Arg-Phe- $\mathrm{NH}_{2}$ (RFamide) motif and acts via $\mathrm{GnIH}$ receptor (GnIHR), a new member of G-protein coupled receptor superfamily (GPR147), to inhibit gonadotropin release and synthesis $(27,28)$. The follow-up studies demonstrated that $\mathrm{GnIH}$ acts as a new key player for regulation of reproduction in birds and mammals $(27,28)$. GnIH is one of the RFamide peptides, and it is also known as RFamide-related peptide (RFRP) in mammals $(27,28)$. It is known that $\mathrm{GnIH}$ acts on gonadotropes in the anterior pituitary and GnRH neurons in the hypothalamus to inhibit gonadotropin release and synthesis via GnIHR (GPR147) in birds and mammals (27-29). Recent evidence further indicates that $\mathrm{GnIH}$ operates at the level of the gonads as an autocrine/ paracrine regulator of steroidogenesis and gametogenesis in birds and mammals (27-29).

Recent studies suggested an inverse relationship between increasing adiposity with regressive changes in testis $(22,30)$. The factors responsible for regulating the inverse association between obesity and testicular activity are not yet known. GnIH is shown to have dual function: it suppresses reproductive activity while promoting fat accumulation by acting as an orexigen in birds and mammals (31-33). It is thus possible that GnIH may be the endocrine mediator between nutritional changes associated with adiposity and changes in the reproductive status. If above hypothesis is true, the GnIH should regulate food intake and promote accumulation of fat in adipose tissue; at the same time, it should exert inhibitory effect on testicular function. Therefore, the aim of this study was to determine the role of $\mathrm{GnIH}$ as a modulator of both testes (testosterone synthesis) as well as adipose tissue (accumulation of fat) function. This was achieved by investigating the effect of $\mathrm{GnIH}$ on changes in nutrients uptake and hormonal synthesis/action in the testis and adipose tissue simultaneously by in vivo study and separately by in vitro study.

\section{MATERIALS AND METHODS}

\section{Animal}

Adult Parkes strain male laboratory mice (Mus musculus) were obtained from the inbred colony maintained in our animal house. All experiments were conducted in accordance with principles and procedures of the 2002 Animal act, India, and approved by Animal Ethical Committee, Banaras Hindu University. The adult mice (13 weeks old) of nearly equal body weight (approximate body weight $=30 \mathrm{~g}$ ) were used in this study. Mice were housed under optimum conditions of temperature $24 \pm 2^{\circ} \mathrm{C}$ and humidity $50 \pm 5 \%$ in a photoperiodically controlled room (12-h light:12-h dark) and were provided with commercial food (Pashu Aahar Kendra, Varanasi, India) and tap water ad libitum.

\section{Chemicals}

GnIH or mRFRP-3 (SIKPSAYLPLRF-NH2) was synthesized by Son et al. (34). Insulin was obtained from torrent Pharmaceuticals Ltd., Mehsana, India. Antibodies to IR $\beta$-subunit, GLUT4, and GLUT8 were purchased from Santa Cruz Biotechnology (Santa Cruz, CA, USA), and protein kinase B (PKB)/AKT was purchased from GeneScript USA Inc. (Piscataway, NJ, USA). All other chemicals were purchased from Merck, New Delhi, India. The specificity of antibodies is shown in Table $\mathbf{1}$.

\section{In Vivo Study}

Mice were injected daily with three different doses (20,200 ng, and $2 \mu \mathrm{g} /$ day) of $\mathrm{GnIH}$ dissolved in normal saline for 8 days $(n=10$ per group), intraperitoneally. Mice in the control group received vehicle only. The dose and duration of GnIH was selected based on the previous study (31). Food intake was measured at every 
TABLE 1 | Details of antibodies used for Western blot.

\begin{tabular}{|c|c|c|c|c|}
\hline Antibody & Target species & $\begin{array}{l}\text { Species raised in; } \\
\text { monoclonal/polyclonal }\end{array}$ & Source & $\begin{array}{c}\text { Concentration (used for } \\
\text { Western blot) }\end{array}$ \\
\hline GLUT4 & Human & Rabbit; polyclonal & $\begin{array}{l}\text { Santa cruz Biotechnology Inc. } \\
(\mathrm{H}-61, \mathrm{SC} 7938)\end{array}$ & $1: 500$ \\
\hline GLUT8 & Human & Rabbit; polyclonal & $\begin{array}{l}\text { Santa cruz Biotechnology Inc. } \\
(\mathrm{N}-60, \text { SC 30108) }\end{array}$ & $1: 500$ \\
\hline Insulin receptor $\beta$ & Human & Rabbit; polyclonal & $\begin{array}{l}\text { Santa cruz Biotechnology Inc. } \\
\text { (C-19, SC 711) }\end{array}$ & $1: 500$ \\
\hline AKT & Human & Rabbit; polyclonal & GeneScript Inc. (A00965-40) & $1: 200$ \\
\hline Actin & $\beta$-Actin & Mouse; monoclonal & Sigma A2228, 128K4813 & $1: 2000$ \\
\hline
\end{tabular}

$24 \mathrm{~h}$. The animals were sacrificed by decapitation under a mild dose of anesthetic ether, $24 \mathrm{~h}$ after the last injection, and blood was collected. Body mass of each mouse was recorded before killing. Testes and adipose tissue were excised out, cleaned, weighed, and kept at $-40^{\circ} \mathrm{C}$ for immunoblot analysis. The adipose tissue accumulated in the abdominal cavity region of the control and treated mice were excised out and weighed. Serum was collected and stored at $-20^{\circ} \mathrm{C}$ untill testosterone assay, glucose assay, and TG assay.

\section{Food Intake Measurement}

All mice were individually housed in standard polypropylene cage with hopper style feeder, for lab blocks keep food waste minimum and wood shavings scattered on the floor. Each mouse was provided with measured amount $(25 \mathrm{~g})$ fresh mice feed between 1,000 and $1,100 \mathrm{~h}$ daily for 8 days, and the leftover food pellets (excluding fecal matter) were weighed at the end of $24 \mathrm{~h}$. The total food consumed by each mouse every day was calculated by subtracting the weight of leftover food from the total amount of food given. From the individual data, average food consumed by the control and treated group were subsequently calculated. The average food consumption was measured on day first, fourth, and eight of the experiment. Average daily food intake was calculated as sum of the average food intake on day first, fourth, and eight and divided by three. The amount of food intake by each mouse showed not much change up to day third, but from day fourth up to day eighth, mice the treated with GnIH showed marked increase. Generally, the mouse consumed more food during night as comparable to day. The control mouse showed no significant change in food intake throughout the study.

\section{In Vitro Study}

\section{Testis Culture}

Adult testes ( $n=8$ testes) were quickly dissected out and cleaned of any adhered fat tissue in Dulbecco modified Eagle's medium (DMEM; Himedia, Mumbai, India) containing $250 \mathrm{IU} / \mathrm{ml}$ penicillin and $250 \mathrm{mg} / \mathrm{ml}$ streptomycin sulfate. The testes were cut into equal pieces (approximate $10 \mathrm{mg}$ in weight) and cultured by the method as described previously (35). Culture medium was a mixture of DMEM (with sodium pyruvate and L-glutamine) and Ham's F-12 $(1: 1 ; v: v)$ (Himedia, Mumbai, India) containing $100 \mathrm{U} / \mathrm{ml}$ penicillin, $100 \mu \mathrm{g} / \mathrm{ml}$ streptomycin, and $0.1 \%$ bovine serum albumin (BSA; Sigma, St Louise, MO, USA). After initial incubation for $2 \mathrm{~h}$ at $37^{\circ} \mathrm{C}$, culture medium was discarded, and testicular slices ( 1 per tube) were finally cultured in 1-ml medium containing $10^{-10}$ and $10^{-9} \mathrm{M} / \mathrm{ml} \mathrm{GnIH}$ along with or without 10 and $100 \mathrm{ng} / \mathrm{ml}$ luteinizing hormone $(\mathrm{LH})$ in a humidified atmosphere with $95 \%$ air and $5 \% \mathrm{CO}_{2}$ to maintain $\mathrm{pH} 7.4$ for $24 \mathrm{~h}$ at $37^{\circ} \mathrm{C}$. The doses of $\mathrm{GnIH}$ and $\mathrm{LH}$ used for the in vitro study were selected from our previous study $(31,36)$. Testes cultured under these conditions appear healthy and do not show any sign of necrosis. Each treatment group was run in triplicate. This is evaluated by Autospan liquid gold-Lactate dehydrogenase (Surat, Gujarat, India) in culture media after $2 \mathrm{~h}$ of incubation at $37^{\circ} \mathrm{C}$. Testicular slices were collected at the end of culture, washed several times with PBS, and stored at $-40^{\circ} \mathrm{C}$ for immunoblot study, and media were collected, stored at $-40^{\circ} \mathrm{C}$ until testosterone assay and glucose uptake (35).

\section{Adipocytes Culture}

White adipose tissue (WAT) collected from abdominal cavity of adult male mouse $(n=6)$ was used to determine the in vitro effects of GnIH with or without insulin on GLUT4, IR, and AKT/PKB protein expression in WAT of male mouse. The dose and duration of RFRP-3 was selected based on previous study (37). We assayed these biochemical markers at three doses of insulin. Culture methods for WAT were adopted according to Roy and Krishna (38). Following collection, WAT was quickly cut into pieces in DMEM (Himedia, Mumbai, Maharashtra, India) containing $250 \mathrm{IU} / \mathrm{ml}$ penicillin and $250 \mathrm{mg} / \mathrm{ml}$ streptomycin sulfate. Pieces of WAT of equal mass were cultured in a mixture of DMEM (with sodium pyruvate and L-glutamine) and Ham's F-12 (1/1 v/v) (Himedia) containing $100 \mathrm{IU} / \mathrm{ml}$ penicillin, $100 \mathrm{mg} / \mathrm{ml}$ streptomycin, and $0.1 \%$ BSA (Sigma, St Louise, MO, USA). After initial incubation for $2 \mathrm{~h}$ at $37^{\circ} \mathrm{C}$, the culture medium was discarded, and pieces of WAT were cultured in 1 -ml medium containing either 1,5 , or $10 \mu \mathrm{g} / \mathrm{ml}$ insulin or $10 \mathrm{ng} / \mathrm{ml} \mathrm{GnIH}$ in a humidified atmosphere with $95 \%$ air and $5 \% \mathrm{CO}_{2}$ to maintain $\mathrm{pH} 7.4$ for $24 \mathrm{~h}$ at $37^{\circ} \mathrm{C}$. Each treatment group was run in triplicate. After culture, WAT was collected, washed several times with phosphate buffer saline (PBS), and kept frozen at $-40^{\circ} \mathrm{C}$ until immunoblot assay, and media were collected, stored at $-40^{\circ} \mathrm{C}$ until glucose uptake (38).

\section{Immunoblot}

The testes and WATs collected at the end of in vivo and in vitro studies were processed for protein extraction using the method described earlier $(39,40)$. Western blot analysis was performed as 
previously described (38). In short, a 20\% homogenate (w/v) of adipose tissue was made in suspension buffer containing $0.1 \mathrm{M} \mathrm{NaCl}$, 0.01M Tris-HCl (pH 7.6), 0.001M EDTA ( $\mathrm{pH} 8.0$ ), and $10 \mu \mathrm{g} / \mathrm{ml}$ phenylmethylsulfonyl fluoride. The homogenate was centrifuged at $5,000 \mathrm{~g}$ and at $4^{\circ} \mathrm{C}$ for $15 \mathrm{~min}$; the supernatant was extracted with an equal volume of chloroform and the aqueous phase was recovered. Equal amounts of proteins $(40 \mu \mathrm{g})$ as determined by Folin's method were used for $10 \%$ SDS-PAGE. Thereafter, proteins were transferred electrophoretically to a PVDF membrane (Millipore India Pvt. Ltd., Bangalore, Karnataka, India) overnight at $4^{\circ} \mathrm{C}$. Membranes were blocked for $1 \mathrm{~h}$ with Tris-buffered saline [TBS; Tris $50 \mathrm{mM}$ (pH 7.5), $\mathrm{NaCl} 150 \mathrm{mM}, 0.02 \%$ Tween 20] containing $5 \%$ fat-free dry milk. The membranes were further incubated with primary antibody (see Table 1) for $1 \mathrm{~h}$ in blocking solution. Immunodetection was performed with anti-rabbit IgG conjugated horseradish peroxidase $(1: 1,000)$ for $4 \mathrm{~h}$. Finally, the blot was washed three times with TBS and developed with an enhanced chemiluminescence (ECL) detection system (Bio-Rad, Hercules, CA, USA). Similarly, a blot was developed for $\beta$-actin (Sigma-Aldrich, India) at a dilution of 1:1,000 as a loading control. Immunoreactive bands were later quantified using Image J software (Image J 1.36, NIH, Bethesda, MD, USA) (38).

\section{Testosterone Assay}

Testosterone was measured by using ELISA kit purchased from Dia Metra, Giustozzi, Foligno (PG) Italy (LOT No: DKO002) as described earlier (31). The $25 \mu \mathrm{l}$ of standard, control, or sample and $100 \mu \mathrm{l}$ of diluted conjugate solution were added to each ELISA plate. The ELISA plate was then incubated at $37^{\circ} \mathrm{C}$ for $1 \mathrm{~h}$ with mild shaking. The wells were aspirated and washed several times with distilled water. After adding $100 \mu \mathrm{l}$ of the tetramethyl benzidine (TMB) chromagen substrate to each well, ELISA plate was incubated at room temperature for $15 \mathrm{~min}$ in the dark. Finally, stop solution $(100 \mu \mathrm{l})$ was added, and absorbance was recorded at $450 \mathrm{~nm}$ using a microplate reader. The standard curve ranged from 0.2 to $16 \mathrm{ng} / \mathrm{ml}(31)$.

\section{Glucose Assay}

Blood glucose was measured by the glucose oxidase method using a commercially available automated glucose analyzer (Span Diagnostics Ltd., Surat, Gujarat, India) with $10 \mu$ l of blood.

\section{Serum Triglyceride Assay and Adipose Tissue Triglyceride Content}

Triglyceride in blood was measured using a commercially available colorimetric kit (GPO-Trinder) (Span Diagnostics Ltd., Surat, Gujarat, India), and TG in WAT was measured with minor modifications $(41,42)$. A $20 \%$ homogenate (w/v) of WAT was prepared in PBS. Then TG was extracted from the homogenate overnight in heptane:isopropanol $(3: 2)$ at $4^{\circ} \mathrm{C}$. TG content was measured using a colorimetric kit (GPO-Trinder) from Span Diagnostics Ltd., Surat, Gujarat, India. Results are expressed as milligram TG per milligram protein.

\section{Glucose Uptake Assay: In Vitro Study}

The media stored at $-20^{\circ} \mathrm{C}$ was used for glucose uptake assay according to Roy and Krishna (38) and Banerjee et al. (16), who described earlier to determine the glucose by quantitative colorimetric method. The glucose concentration of the media was measured at the beginning as well as at the end of culture, and the difference between initial concentration of media and final concentration of media after the $24 \mathrm{~h}$ culture was taken as the amount of glucose uptake by the WAT or testis. Each group was run in triplicates. The intra-assay coefficient of variation $(\mathrm{CV})$ was $<7.5 \%$.

\section{Statistical Analysis}

Data were analyzed using one-way ANOVA followed by Bonferroni's test using SPSS software 16 for Windows (SPSS Inc., Chicago, IL, USA). Correlation studies were performed to compare data from different groups. The differences were considered significant at the level of $p<0.05$.

\section{RESULTS}

\section{Changes in Daily Food Intake}

Table 2 shows the effect of in vivo administration of $\mathrm{GnIH}$ on food intake of adult male mice. Three different doses $(20,200 \mathrm{ng}$, and $2 \mu \mathrm{g} /$ day $)$ of $\mathrm{GnIH}$ administration caused a dose-dependent increase in food intake. A significant increase $(p<0.05)$ in food intake was noticed in mice treated with a high dose ( $2 \mu \mathrm{g} /$ day) of $\mathrm{GnIH}$ for 8 days as compared with the control.

\section{Body Mass and Adipose Tissue Mass}

The body mass showed significant $(p<0.05)$ increase by the treatment with moderate and high doses (200 ng and $2 \mu \mathrm{g}$ /day) of $\mathrm{GnIH}$ as compared with the control. The adipose tissue mass also changed in response to the treatment with different doses (20, $200 \mathrm{ng}$, and $2 \mu \mathrm{g} /$ day) of GnIH. The adipose tissue mass showed no significant change when treated with a low dose (20 ng/day) of $\mathrm{GnIH}$, whereas it increased significantly $(p<0.05)$ in response to moderate and high doses of GnIH treatments as compared with the control (see Table 3).

\section{Circulating Triglyceride, Glucose, and Testosterone Levels}

The treatment with different doses $(20,200 \mathrm{ng}$, and $2 \mu \mathrm{g} /$ day $)$ of $\mathrm{GnIH}$ showed significant variation in circulating levels of TG s $(p<0.05)$ and glucose $(p<0.05)$. Both TG $s$ and glucose

TABLE 2 | Effect of GnlH on average daily food intake in mice (in vivo).

\begin{tabular}{lcccr}
\hline $\begin{array}{l}\text { Doses of } \\
\text { GnIH }\end{array}$ & \multicolumn{3}{c}{ Daily food intake (g) } & $\begin{array}{c}\text { Average daily } \\
\text { food intake (g) }\end{array}$ \\
\cline { 2 - 4 } & Day 1 & Day 4 & Day 8 & \\
\hline Control & $18.4 \pm 0.095$ & $18.1 \pm 0.170$ & $17.8 \pm 0.105$ & $18.1 \pm 0.173$ \\
$20 \mathrm{ng} /$ day & $17.08 \pm 0.04$ & $16.2 \pm 0.138$ & $17.8 \pm 0.084$ & $17.05 \pm 0.482$ \\
$200 \mathrm{ng} /$ day & $18.01 \pm 0.28$ & $22.40 \pm 0.44^{*}$ & $24.55 \pm 0.183^{*}$ & $21.32 \pm 1.69^{\star}$ \\
$2 \mu \mathrm{g} /$ day & $22 \pm 0.219^{*}$ & $24.55 \pm 0.131^{*}$ & $25 \pm 0.002^{*}$ & $23.85 \pm 0.93^{\star}$
\end{tabular}

Values are mean \pm SEM for five animals (daily food intake).

*Significantly different from controls $(p<0.05)$ by one-way analysis of variance (ANOVA) followed by Bonferroni's test. 
TABLE 3 | Effect of GnIH on body mass, WAT mass, adipose tissue TG, testicular glucose, serum TG, and serum glucose mice (in vivo).

\begin{tabular}{|c|c|c|c|c|c|c|}
\hline \multirow{2}{*}{$\begin{array}{l}\text { Doses of } \\
\text { GnIH }\end{array}$} & \multirow{2}{*}{$\begin{array}{l}\text { Body mass } \\
\text { (g) }\end{array}$} & \multirow{2}{*}{$\begin{array}{l}\text { White adipose } \\
\text { tissue mass }(g)\end{array}$} & \multicolumn{2}{|c|}{ Tissue } & \multicolumn{2}{|c|}{ Serum } \\
\hline & & & $\begin{array}{l}\text { Adipose tissue Triglyceride } \\
\text { concentration (TG/mg protein) }\end{array}$ & $\begin{array}{l}\text { Testicular glucose concentration } \\
\text { (mg/mg testis wt) }\end{array}$ & $\begin{array}{l}\text { Triglyceride } \\
\text { level (mg/dl) }\end{array}$ & $\begin{array}{l}\text { Glucose level } \\
\text { (mg/dl) }\end{array}$ \\
\hline Control & $33.258 \pm 0.23$ & $2.121 \pm 0.10$ & $442.8 \pm 5.34$ & $4.4 \pm 0.166$ & $140.38 \pm 1.58$ & $43.86 \pm 1.68$ \\
\hline 20 ng/day & $33.022 \pm 0.56$ & $1.524 \pm 0.04$ & $179.8 \pm 3.32^{\star}$ & $3.8 \pm 0.12$ & $229.25 \pm 2.01^{*}$ & $85.65 \pm 1.49^{\star}$ \\
\hline 200 ng/day & $34.236 \pm 0.30$ & $2.88 \pm 0.08^{*}$ & $256.56 \pm 10.86^{\star}$ & $3.2 \pm 0.176^{\star}$ & $196.57 \pm 1.43^{\star}$ & $65.33 \pm 1.85^{\star}$ \\
\hline $2 \mu \mathrm{g} /$ day & $38.89 \pm 0.38^{\star}$ & $3.22 \pm 0.05^{\star}$ & $602.65 \pm 5.85^{\star}$ & $2.5 \pm 0.17^{\star}$ & $93.36 \pm 4.13^{\star}$ & $31.65 \pm 1.43^{*}$ \\
\hline
\end{tabular}

Values are mean \pm SEM for five animals.

*Significantly different from controls $(p<0.05)$ by one-way analysis of variance (ANOVA) followed by Bonferroni's test.

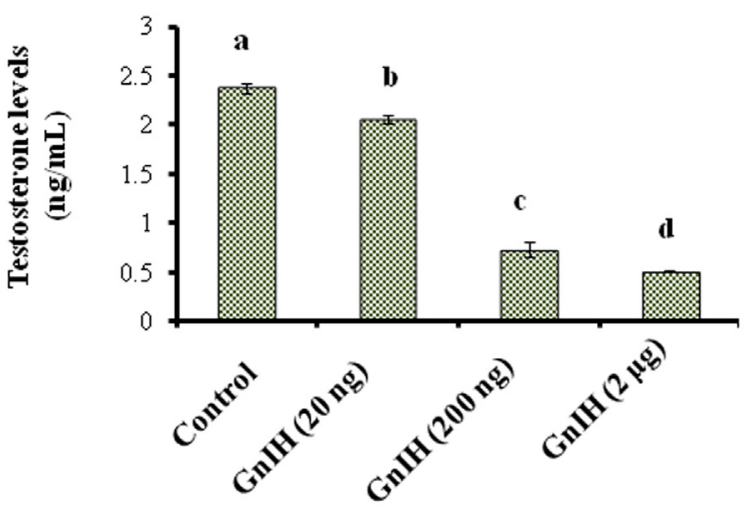

FIGURE 1 | The mice treated with different doses $(20,200 \mathrm{ng}$, and $2 \boldsymbol{\mu g} /$ day) of GnlH on synthesis of testosterone in testis of mice. $\mathrm{GnlH}$ showed significantly decreased $(p<0.05)$ synthesis of testosterone levels in dose-dependent manner as compare to control (a, $p<0.05)$.

levels were significantly $(p<0.05)$ increased in response to low and moderate doses (20 and $200 \mathrm{ng}$ /day) of GnIH treatment as compared with the control. However, both TGs and glucose levels were significantly $(p<0.05)$ decreased with a high dose $(2 \mu \mathrm{g} /$ day $)$ of $\mathrm{GnIH}$ in comparison to the control (Table 3 ). The treatment with different doses of $\mathrm{GnIH}$ showed a significant $(p<0.05)$ dosedependent decline in circulating testosterone levels as compared with the control (Figure 1).

\section{Changes in the Level of Triglycerides and in the Expression of GLUT4 and GLUT8 and IR Proteins in the Adipose Tissue}

The treatment with low and moderate doses (20 and $200 \mathrm{ng} /$ day) of GnIH showed significant decrease $(p<0.05)$ in the TG level in the adipose tissue, whereas a high dose $(2 \mu \mathrm{g} /$ day $)$ of $\mathrm{GnIH}$ treatment showed a significant increase $(p<0.05)$ in the TGs level in the adipose tissue as compared with the control $(p<0.05)$ (Table 3).

The treatment with low dose (20 ng/day) of GnIH showed significant $(p<0.05)$ increase in the expressions of IR and GLUT8 proteins in the adipose tissue as compared with the control. However, moderate and high doses (200 ng and $2 \mu \mathrm{g}$ /day) of GnIH showed significant $(p<0.05)$ decreased expressions of IR and GLUT8 proteins as compared with the control (Figures 2A,B). A low dose (20 ng/day) of $\mathrm{GnIH}$ treatment showed significant $(p<0.05)$ decreased expression of GLUT4 whereas a high dose $(2 \mu \mathrm{g} /$ day $)$ showed significant $(p<0.05)$ increased expression of GLUT4 as compared with the control in the adipose tissue (Figure 2C).

\section{Changes in the Level of Glucose and in the Expression of GLUT8 and IR Proteins in the Testis}

The treatment with low and moderate doses (20 and $200 \mathrm{ng} /$ day) of GnIH showed significant $(p<0.05)$ decrease in glucose concentrations in the testis as compared with the control. Whereas the treatment with a high dose $(2 \mu \mathrm{g} /$ day $)$ caused a significant $(p<0.05)$ increase in glucose level in the testis as compared to treatment with the moderate dose (Table 3 ).

The treatment with low and moderate doses of GnIH showed significant $(p<0.05)$ decrease in expression of IR protein in the testis as compared with the control, whereas the treatment with a high dose caused a significant $(p<0.05)$ increase in the expression of IR protein as compared with the moderate dose treatment (Figure 3A).

The treatment with a moderate dose (200 ng/day) of $\mathrm{GnIH}$ showed a significant $(p<0.05)$ decrease in the expression of GLUT8 protein in the testis as compared with the control, whereas the treatment with a high dose $(2 \mu \mathrm{g} /$ day $)$ caused a significant $(p<0.05)$ increase in expression of GLUT8 protein in the testis as compared with the moderate dose treatment (Figure 3B).

\section{Effects of In Vitro Treatment of GnIH with or without LH in the Testis of Mice}

\section{Effect on Glucose Uptake}

The in vitro treatment with low and high doses $\left(10^{-10}\right.$ and $10^{-9} \mathrm{M} /$ $\mathrm{ml}$ ) of $\mathrm{GnIH}$ showed a dose-dependent suppression of glucose uptake in the testis. The treatment with low and high (10 and $100 \mathrm{ng} / \mathrm{ml}$ ) doses of LH alone showed a dose-dependent significant $(p<0.05)$ increase in glucose uptake by the testis. The treatment with a high dose of $\mathrm{LH}$ together with a high dose of $\mathrm{GnIH}$ showed a significant $(p<0.05)$ increase in uptake of glucose by the testis as compared with the control (Figure 4A).

\section{Effect on the Expression of GLUT8 Protein}

The in vitro treatment with low and high doses $\left(10^{-10}\right.$ and $\left.10^{-9} \mathrm{M} / \mathrm{ml}\right)$ of $\mathrm{GnIH}$ showed a significant $(p<0.05)$ decrease in the expression of GLUT8 protein. However, the in vitro treatment 


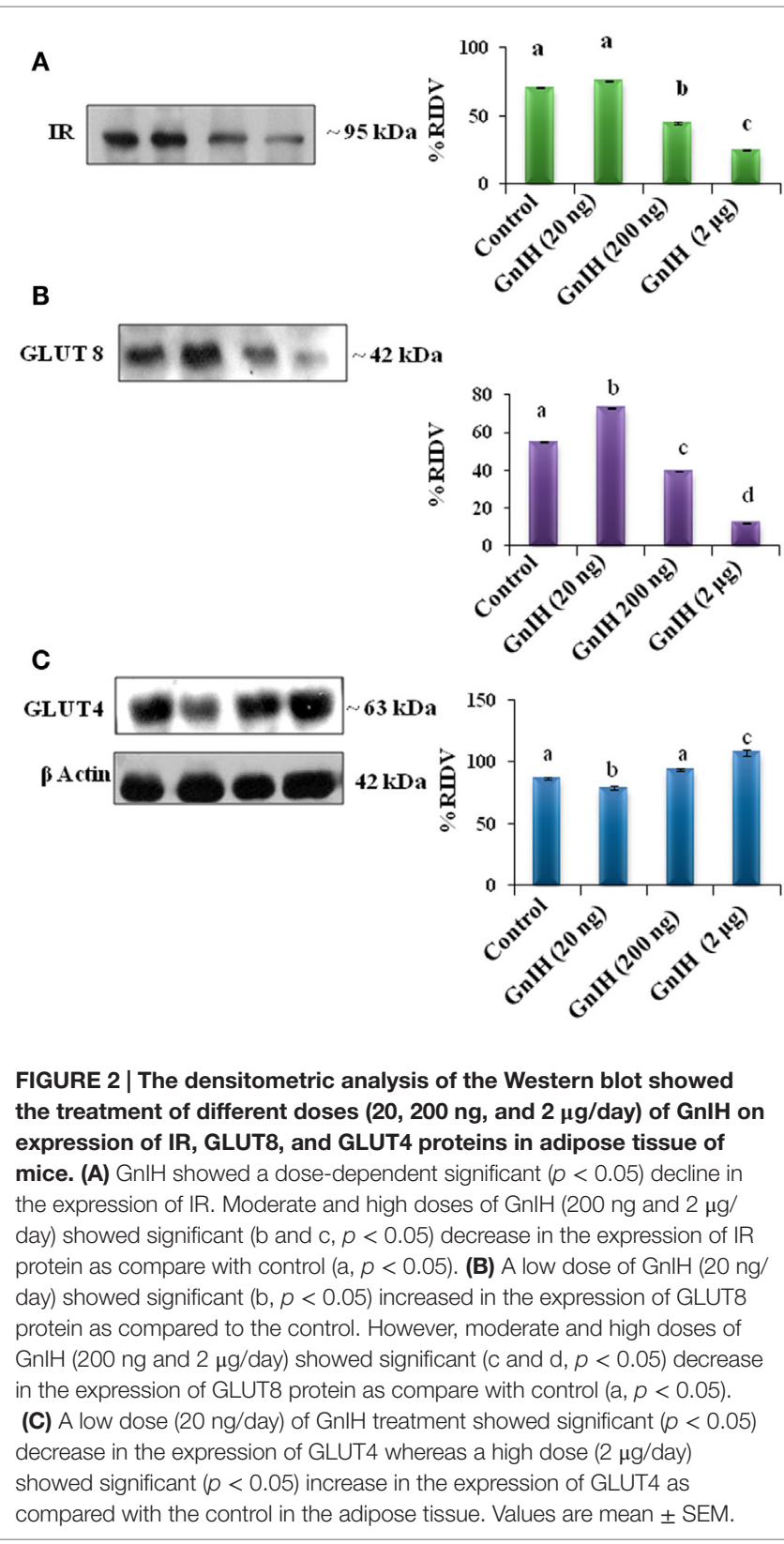

with low and high doses (10 and $100 \mathrm{ng} / \mathrm{ml})$ of $\mathrm{LH}$ showed a dose-dependent significant $(p<0.05)$ increase in the expression of GLUT8 protein. The in vitro treatment with a high dose of $\mathrm{LH}$ with a high dose of GnIH showed a significant increase in the expression of GLUT8 protein in the testis as compared with the control (Figure 4B).

\section{Effects of In Vitro Treatment of Insulin to the Adipose Tissue of Mice Effects on the Expressions of IR, GLUT4, and AKT Proteins in the Adipose Tissue}

The adipose tissue treated in vitro with 1,5 , and $10 \mu \mathrm{g} / \mathrm{ml}$ doses of insulin showed dose-dependent significant $(p<0.05)$ increase

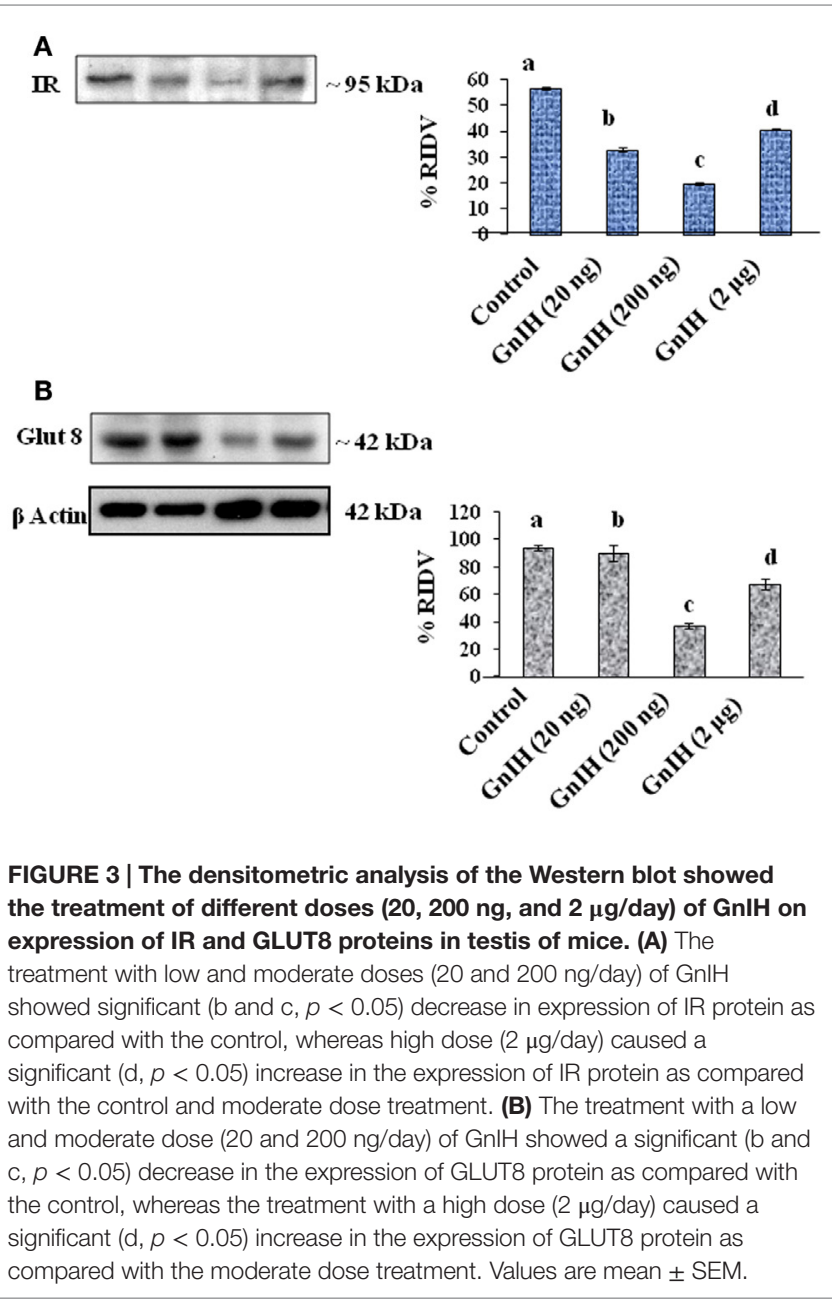

in expression of IR, GLUT4 proteins in the adipose tissue as compared with the control (Figures 5A,B).

The adipose tissue treated in vitro with different doses $(1,5$, and $10 \mu \mathrm{g} / \mathrm{ml}$ ) of insulin showed dose-dependent significant $(p<0.05)$ increase in the expression of AKT protein in adipose tissue as compare to the control (Figure 6).

\section{Effects of In Vitro Treatment of GnIH Either Alone Or Together with Insulin to the Adipose Tissue of Mice The Expression of IR Protein}

The adipose tissue treated in vitro with different doses $\left(10^{-10}\right.$ and $\left.10^{-9} \mathrm{M} / \mathrm{ml}\right)$ of $\mathrm{GnIH}$ with or without insulin $(10 \mu \mathrm{g} / \mathrm{ml})$ showed a dose-dependent significant $(p<0.05)$ decrease in expression of IR protein as compared with the control. The treatment with a high dose of $\mathrm{GnIH}$ together with insulin showed a significant $(p<0.05)$ increase in the expression of IR protein in the adipose tissue as compared with the only GnIH-treated group (Figure 7A).

\section{The Expression of GLUT4 Protein}

The adipose tissue treated in vitro with different doses $\left(10^{-10}\right.$ and $\left.10^{-9} \mathrm{M} / \mathrm{ml}\right)$ of $\mathrm{GnIH}$ with or without insulin $(10 \mu \mathrm{g} / \mathrm{ml})$ showed a 


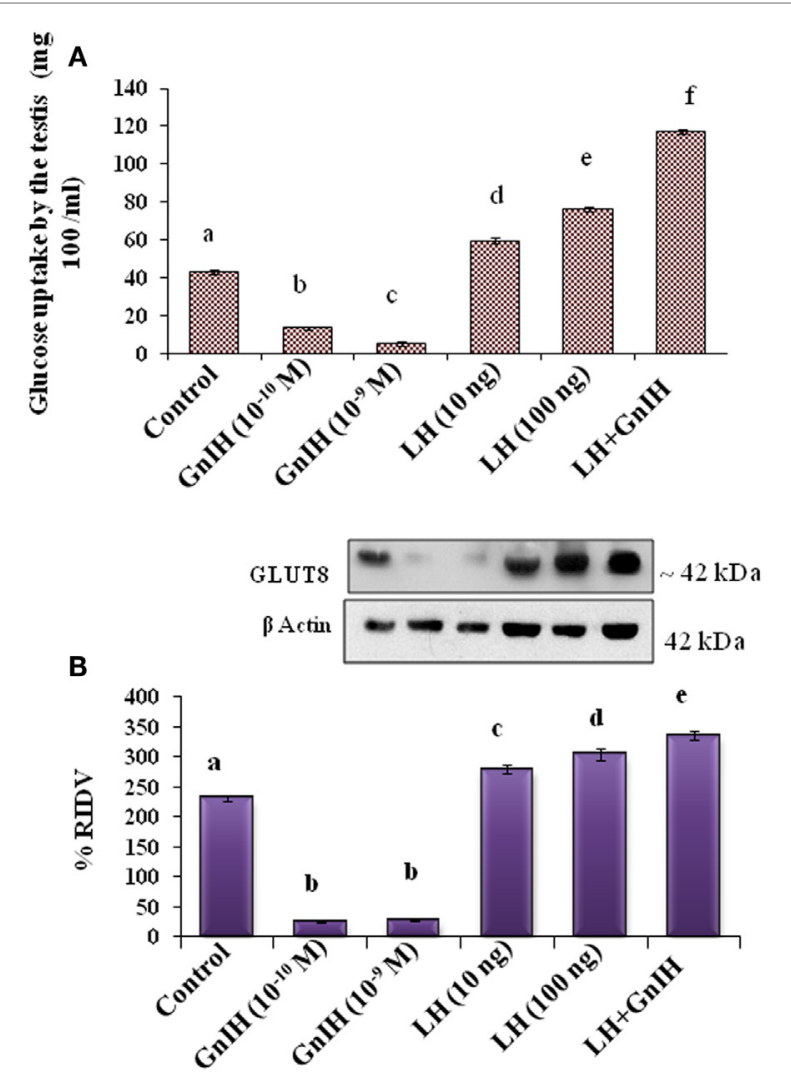

FIGURE 4 | The in vitro treatment of different doses $\left(10^{-10}\right.$ and $10^{-9} \mathrm{M} /$ $\mathrm{ml}$ ) of GnIH with or without different doses (10 and $100 \mathrm{ng} / \mathrm{ml}$ ) of $\mathrm{LH}$ showed effect on glucose uptake by the testis and expression of GLUT 8 protein. (A) The treatment with low and high doses $\left(10^{-10}\right.$ and $10^{-9} \mathrm{M} / \mathrm{ml}$ ) of $\mathrm{GnlH}$ showed a dose-dependent suppression of glucose uptake in the testis. The treatment with low and high (10 and $100 \mathrm{ng} / \mathrm{ml}$ ) doses of LH alone showed a dose-dependent significant ( $d$ and e, $p<0.05$ ) increase in glucose uptake by the testis. A high dose of LH together with a high dose of GnlH showed a significant (f, $p<0.05$ ) increase in uptake of glucose by the testis as compared with the control (a, $p<0.05)$. (B) The treatment with low and high doses $\left(10^{-10}\right.$ and $\left.10^{-9} \mathrm{M} / \mathrm{ml}\right)$ of $\mathrm{GnlH}$ showed a significant (b, $p<0.05$ ) decrease in the expression of GLUT8 protein. The treatment with low and high doses (10 and $100 \mathrm{ng} / \mathrm{ml}$ ) of LH showed a dosedependent significant (c and $d, p<0.05$ ) increase in the expression of GLUT8 protein. A high dose of LH with a high dose of GnIH showed a significant ( $\mathrm{f}, p<0.05$ ) increase in the expression of GLUT8 protein in the testis as compared with the control $(a, p<0.05)$.

dose-dependent significant $(p<0.05)$ increase in the expression of GLUT 4 protein as compared with the control. The treatment with the high dose of GnIH together with insulin showed a significant $(p<0.05)$ increase in the expression of GLUT4 protein in the adipose tissue as compared with only GnIHtreated group (Figure 7B).

\section{The Expression of AKT/PBK Protein}

The adipose tissue treated in vitro with different doses $\left(10^{-10}\right.$ and $10^{-9} \mathrm{M} / \mathrm{ml}$ ) of $\mathrm{GnIH}$ alone showed a dose-dependent significant $(p<0.05)$ decrease in the expression of AKT protein as compared with the control. The treatment with a high dose of $\mathrm{GnIH}$
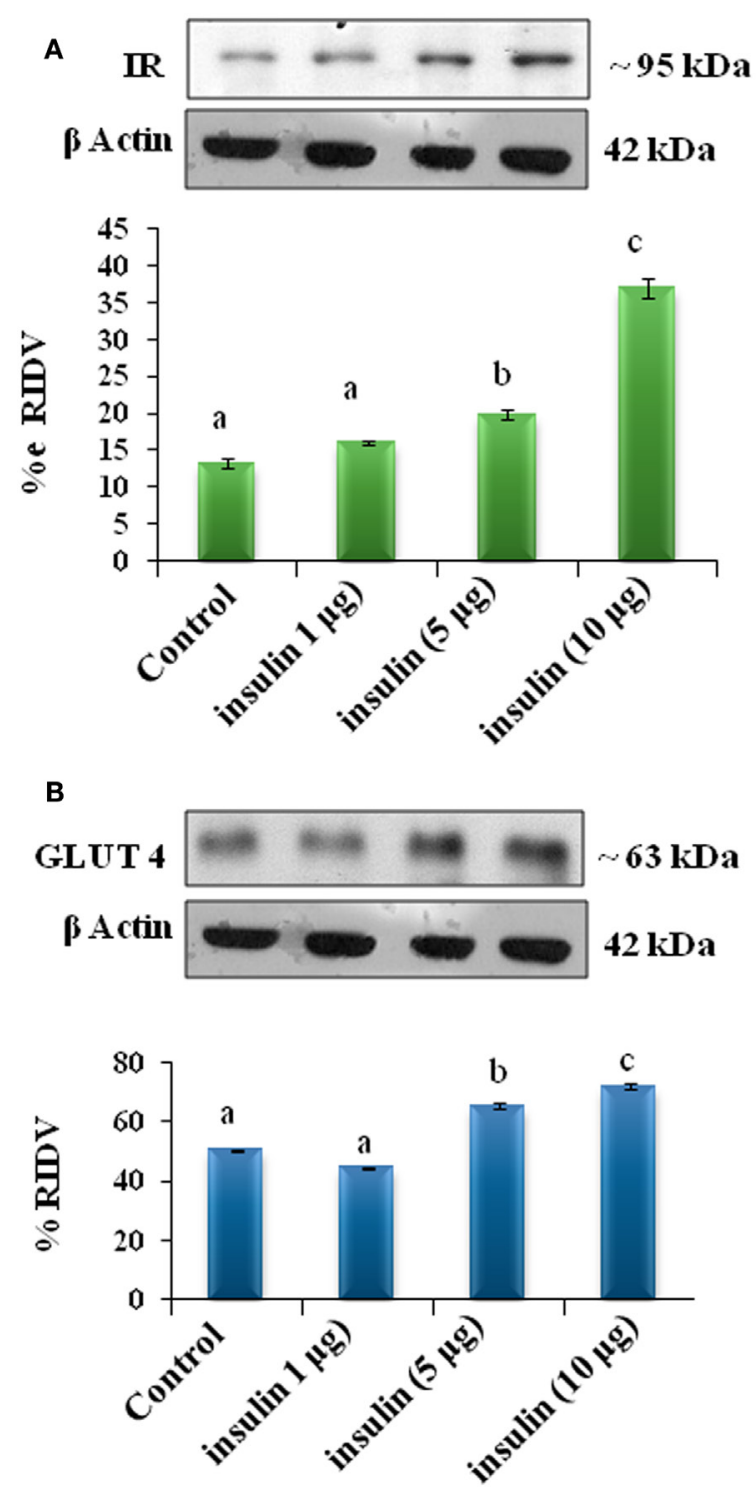

FIGURE 5 | The in vitro treatment with different doses of insulin (1, 5, and $10 \mu \mathrm{g} / \mathrm{ml}$ ) on expression of insulin receptor and GLUT4 proteins in the adipose tissue. The treatment of insulin showed dose-dependent significant (b, c and d, $p<0.05$ ) increase in expression of $I R(A)$ and (b and c, $p<0.05)$ GLUT4 (B) proteins in the adipose tissue as compared with the control $(\mathrm{a}, p<0.05)$.

together with insulin showed a significant $(p<0.05)$ increase in the expression of AKT protein in the adipose tissue as compared with the only GnIH-treated group (Figure 8).

\section{Correlation Study}

The results of correlation study studies are summarized in Table 4. A significant $(p<0.05)$ correlation was found between changes in circulating testosterone levels, glucose levels, and TG levels with changes in the rate of expression of GLUT4, GLUT8, and IR in adipose tissue and testis of mice treated with $\mathrm{GnIH}$. 

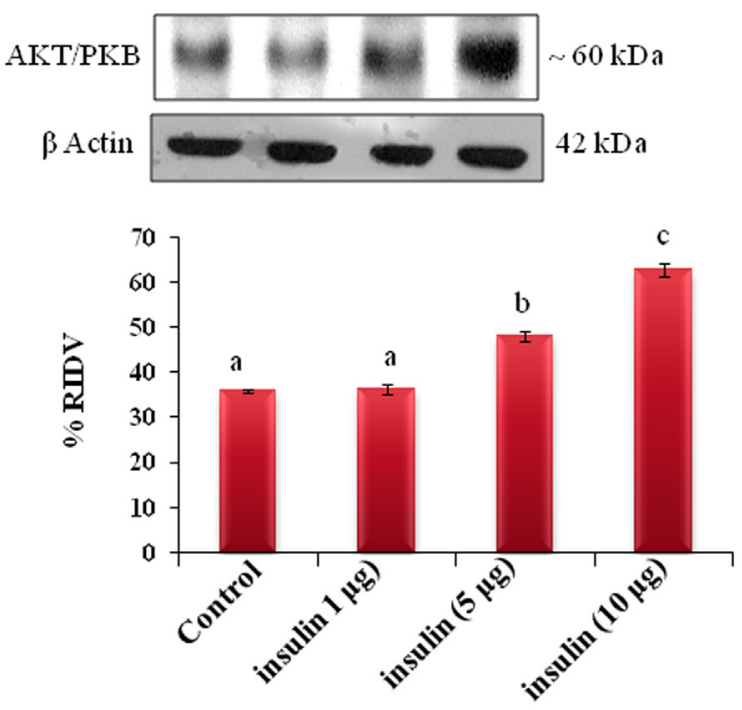

FIGURE 6 | The in vitro treatment of adipose tissue with different doses $(1,5$, and $10 \mu \mathrm{g} / \mathrm{ml})$ of insulin showed dose-dependent significant (b, c, and $d, p<0.05)$ increase in the expression of AKT/ PKB protein in adipose tissue as compare to the control $(a, p<0.05)$

\section{DISCUSSION}

For the first time, the results of present study provide the experimental proof suggesting an active participation of $\mathrm{GnIH}$ in increased food intake and glucose and TGs uptake in adipose tissue results in fat accumulation and increased body mass whereas in testis, GnIH suppressed glucose uptake resulting in decreased testosterone synthesis. In the present study, three different doses of $\mathrm{GnIH}$ were used, and the results showed dose-dependent changes in majority of the studies. But treatment with the high dose of $\mathrm{GnIH}(2 \mu \mathrm{g} /$ day $)$ showed a significant variation as compared with the control, thus the results of high dose of GnIH treatment are generally considered for discussion.

The mice treated in vivo with GnIH showed both dose- and duration-dependent increase in food intake. High dose of RFRP-3 ( $2 \mu \mathrm{g} /$ day) showed increased food intake on day 1 itself as compared with the control, whereas moderate dose of RFRP-3 (200 ng/day) showed significant increase in food intake on day 4 . The lower dose of RFRP-3 did not show any significant increases in food intake until day 8 (Table 2). Thus moderate and high doses of $\mathrm{GnIH}$ induced a significant increase in food intake as compared to the control, and it is therefore considered that $\mathrm{GnIH}$ increases food intake in mice. In addition, the mice treated in vivo with GnIH for 8 days showed increased accumulation of adipose tissue and body mass as compared to the control. These findings are in agreement with earlier observations in chicks and rat $(32,43)$ and suggest that $\mathrm{GnIH}$ is one of the orexigenic peptide in mammals. An earlier study has demonstrated the presence of RFRP-3 receptor (GPR147) in the adipose tissue (44). The GnIH containing neurons was shown in contact with the neurons containing neuropeptides, such as neuropeptideY, pro-opio melanocortin, orexin, and melanopeptide, which are
A
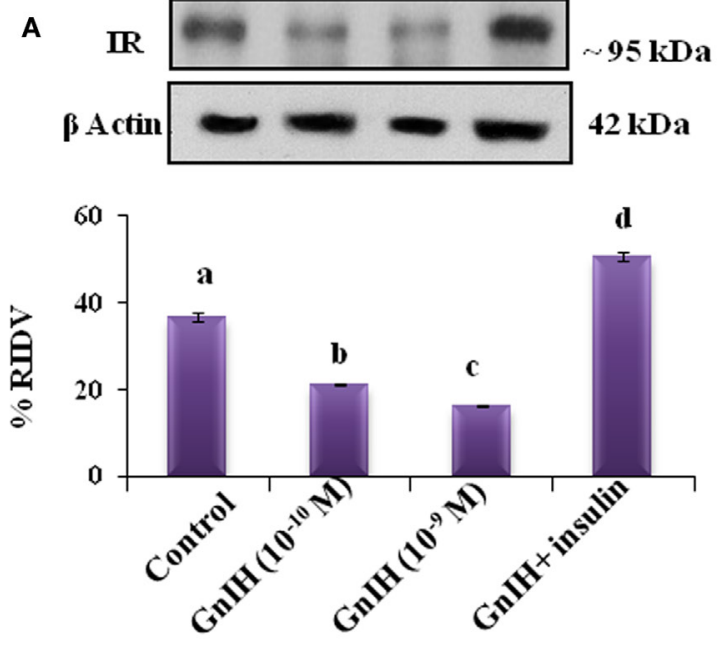

B
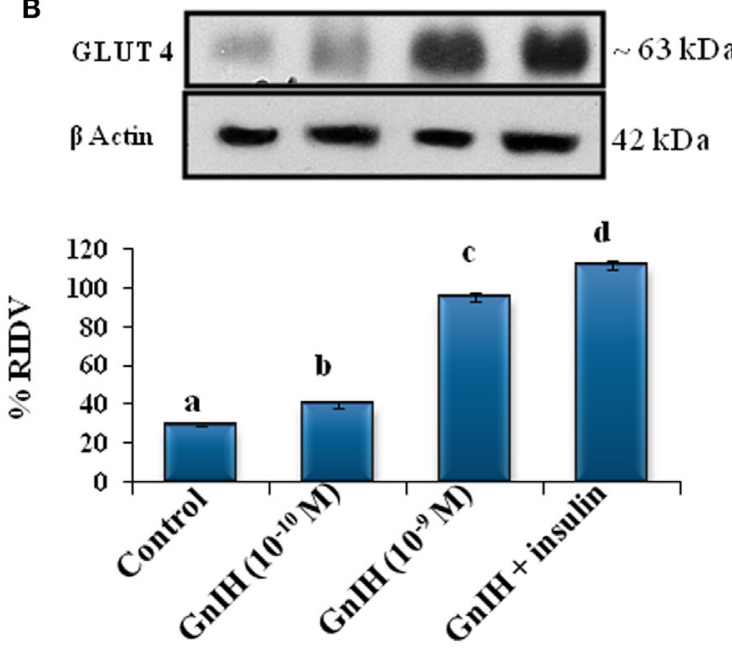

FIGURE 7 | The in vitro treatment of adipose tissue with different doses $\left(10^{-10} \mathrm{M}\right.$ and $\left.10^{-9} \mathrm{M} / \mathrm{ml}\right)$ of $\mathrm{GnIH}$ with or without insulin $(10 \mu \mathrm{g} / \mathrm{ml})$ showed $(A)$ a dose-dependent (b and c, $p<0.05)$ significant decrease in expression of IR protein as compared with the control with $\left(10^{-10} \mathbf{M}\right.$ and $\left.\mathbf{1 0}^{-9} \mathbf{M} / \mathbf{m l}\right)$ of $\mathbf{G n I H}$. The treatment with a high dose of $\mathrm{GnlH}$ together with insulin showed a significant (d, $p<0.05$ ) increase in the expression of IR protein in as compared with the only $\mathrm{GnIH}$-treated group. (B) The in vitro treatment of adipose tissue with different doses $\left(10^{-10}\right.$ and $\left.10^{-9} \mathrm{M} / \mathrm{ml}\right)$ of $\mathrm{GnlH}$ with or without insulin $(10 \mu \mathrm{g} / \mathrm{ml})$ showed a dose-dependent significant $(p<0.05)$ increase in the expression of GLUT 4 protein as compared with the control. The treatment with the high dose of $\mathrm{GnIH}$ together with insulin showed a significant $(d, p<0.05)$ increase in the expression of GLUT4 protein in the adipose tissue as compared with only GnlH-treated group

known modulators of nutritional changes $(28,45,46)$. In an earlier study, where rat was treated with GnRH agonist showed a dose-dependent gain in the body mass (47). It was suggested that GnRH agonist-induced increase in the body mass might be due to neuropeptideY- and/or opioidpeptide-mediated increase in feeding activity in the rats (48). Accordingly, in the present study, $\mathrm{GnIH}$ may act as a modulator of energy homeostasis association with other neuropeptides in the mice. 
Interestingly, in the present study, in vivo treatment of $\mathrm{GnIH}$ showed dose-dependent increase in the expression of GLUT4 protein, but significant decline in the expression of GLUT8 and IR proteins in the adipose tissue. GLUT4, a major isoform of GLUT, is normally found in the insulin-responsive tissue, such as the striated muscle and adipose tissue, and plays a crucial role

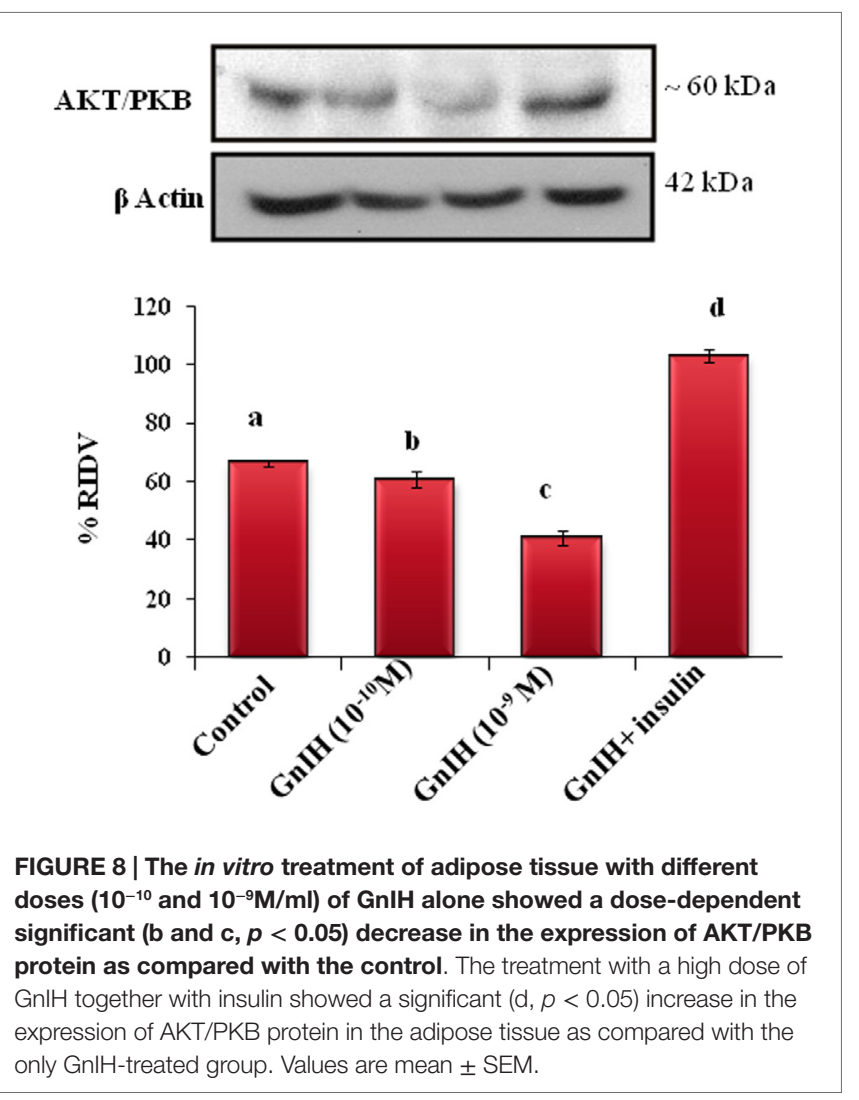

in whole body glucose homeostasis. It is well known that insulin upregulates the expression of GLUT4 protein $(49,50)$. Besides GLUT4, GLUT8, and GLUT12 are other GLUTs regulated by insulin (51). GLUT8 is mainly expressed in the striated muscle, adipose tissue, testis, blastocyst, brain, liver, and kidney $(52,53)$. The upregulation of GLUT4 by GnIH in the adipose tissue is unique findings of this study. Despite increased expression of GLUT4, GnIH treatment caused dose-dependent downregulation of GLUT8 and IR proteins in the adipose tissue. In adipose tissue, expression of GLUT4 is under regulation of insulin, but regulation of GLUT8 is not known. This study also showed a significant positive correlation between changes in expression of IR with GLUT8 protein but showed a negative correlation between the changes in expression of IR with GLUT4 protein in the adipose tissue treated in vivo with GnIH. This suggests that in adipose tissue, expression of GLUT8 protein changes with IR level. Furthermore, the in vitro study confirmed the in vivo observations of GnIH-induced upregulation of GLUT4 together with the downregulation of IR proteins in the adipose tissue. These observations thus suggest that $\mathrm{GnIH}$ increases glucose uptake in the adipose tissue stimulating expression of GLUT4.

The in vivo treatment with high dose of GnIH showed significantly increased synthesis of TGs in adipose tissue. GnIHinduced increased expression of GLUT4 suggests increased uptake of glucose into adipose tissue, which subsequently may get converted into TG and free fatty acid, the storage form of nutrients in the adipocytes. The mice treated with $\mathrm{GnIH}$ in vivo showed dose-dependent significant decline in the circulating TG and glucose levels. Simultaneously with decline in circulating TG levels, this study showed significant increase in the TG level in the adipose tissue as compared with the control. The significant inverse correlation between changes in TG level in the serum verses adipose tissue suggest that GnIH may be responsible for increased transport of TGs from serum to adipose tissue. This

TABLE 4 | Correlation studies of GnIH treatment between the different parameters in adipose tissue and testis (in vivo).

\begin{tabular}{|c|c|c|c|c|c|c|c|c|c|c|}
\hline & \multirow{2}{*}{$\begin{array}{c}\text { Adipose } \\
\text { tissue } \\
\text { TG }\end{array}$} & \multirow[t]{2}{*}{ Serum TG } & \multirow{2}{*}{$\begin{array}{l}\text { Serum } \\
\text { glucose }\end{array}$} & \multirow{2}{*}{$\begin{array}{c}\text { Testicular } \\
\text { glucose } \\
\text { level }\end{array}$} & \multirow{2}{*}{$\begin{array}{c}\text { Testosterone } \\
\text { level }\end{array}$} & \multicolumn{3}{|c|}{ Adipose tissue } & \multicolumn{2}{|c|}{ Testis } \\
\hline & & & & & & GLUT4 & GLUT8 & IR & GLUT8 & IR \\
\hline $\begin{array}{l}\text { Adipose } \\
\text { tissue TG }\end{array}$ & & $\begin{array}{c}r=-0.99 \\
p<0.05\end{array}$ & $\begin{array}{c}r=-0.97 \\
p<0.05\end{array}$ & NS & NS & $\begin{array}{l}r=0.89 \\
p<0.05\end{array}$ & $\begin{array}{c}r=-0.67 \\
p<0.05\end{array}$ & $\begin{array}{c}r=-0.57 \\
p<0.05\end{array}$ & NS & $\begin{array}{l}r=0.57 \\
p<0.05\end{array}$ \\
\hline Serum TG & & & $\begin{array}{l}r=0.98 \\
p<0.05\end{array}$ & NS & NS & $\begin{array}{c}r=-0.91 \\
p<0.05\end{array}$ & $\begin{array}{l}r=0.67 \\
p<0.05\end{array}$ & $\begin{array}{l}r=0.57 \\
p<0.05\end{array}$ & NS & $\begin{array}{l}r=0.56 \\
p<0.05\end{array}$ \\
\hline $\begin{array}{l}\text { Serum } \\
\text { glucose }\end{array}$ & & & & NS & NS & $\begin{array}{c}r=-0.93 \\
p<0.05\end{array}$ & $\begin{array}{l}r=0.63 \\
p<0.05\end{array}$ & NS & NS & $\begin{array}{c}r=-0.56 \\
p<0.05\end{array}$ \\
\hline $\begin{array}{l}\text { Testicular } \\
\text { glucose } \\
\text { level }\end{array}$ & & & & & $\begin{array}{l}r=0.94 \\
p<0.05\end{array}$ & & & & $\begin{array}{l}r=0.63 \\
p<0.05\end{array}$ & NS \\
\hline $\begin{array}{l}\text { Testosterone } \\
\text { level }\end{array}$ & & & & & & & & & $\begin{array}{l}r=0.82 \\
p<0.05\end{array}$ & $\begin{array}{l}r=0.56 \\
p<0.05\end{array}$ \\
\hline GLUT4 & & & & & & & $\begin{array}{c}r=-0.97 \\
p<0.05\end{array}$ & $\begin{array}{c}r=-0.94 \\
p<0.05\end{array}$ & NS & NS \\
\hline GLUT8 & & & & & & & & $\begin{array}{l}r=0.99 \\
p<0.05\end{array}$ & NS & $\begin{array}{l}r=0.78 \\
p<0.05\end{array}$ \\
\hline
\end{tabular}

NS, not significant.

Values are significantly different at $p<0.05$. 
consequently may be responsible for increased accumulation of fat in the adipocytes and consequently increase in body mass.

The mice treated in vivo with $\mathrm{GnIH}$ showed a dose-dependent significant $(p<0.05)$ decline in the level of testosterone as compared with the control. The earlier study on hamster testes revealed the expression of RFRP-receptor (GPR147). Thus, suggesting autocrine or paracrine role of RFRP in testis (54). The $\mathrm{GnIH}$ treatment in vivo also showed a significant decline in the expression of GLUT8 and IR proteins together with decreased concentration of glucose in the testis. This finding thus suggests that the mice treated with $\mathrm{GnIH}$ caused reduced availability of glucose to the testis; this consequently may be responsible for the decreased testosterone synthesis. This finding further confirms our recent study that the decreased availability of glucose to the testis resulted in the decreased steroidogenesis (16). It has earlier been demonstrated that glucose availability also modulates the level of the steroidogenic enzyme nicotinamide adenine dinucleotide phosphate (NADPH) in the testis (55). The in vivo treatment of $\mathrm{GnIH}$ also caused suppressed expression of IR protein in the testis. Since insulin directly affects testicular steroidogenesis via the induction of dosage-sensitive sex reversal, adrenal hypoplasia critical region, on chromosome $\mathrm{X}$, gene 1 (DAX-1) in Leydig cells (56), it possible that GnIH may inhibit steroidogenesis by downregulating IR in the testis.

Similar to in vivo study, the testes treated in vitro with $\mathrm{GnIH}$ also showed significant decreased expression of GLUT8 protein, decreased concentration of glucose, and significant decline in the testosterone synthesis. These findings thus suggest that the GnIH-induced decreased uptake of glucose may be directly responsible for the inhibition of testicular steroidogenesis. This study confirmed the earlier finding that Leydig cells culture in the absence of glucose can synthesis testosterone at very low rate (16, 57). The testis treated in vitro with $\mathrm{LH}$ either alone or together with GnIH showed a stimulatory effect on the glucose uptake together with the increased expression of GLUT8 protein and increased synthesis of testosterone. This study suggests that in presence of physiological concentration of $\mathrm{LH}$, inhibitory effect of $\mathrm{GnIH}$ is suppressed. Our earlier studies have shown that LH or hCG increases glucose uptake by increasing GLUT8 expression in the testis (16). Thus in the physiological condition, when LH in sufficient concentration exist in the plasma, GnIH may facilitate glucose uptake by promoting GLUT8 in testis.

To investigate the signaling pathway of GnIH and insulinmediated glucose uptake, AKT/PKB levels were evaluated in the adipose tissue. The adipose tissue from mice treated with different doses of $\mathrm{GnIH}$ with or without insulin in vitro showed a significant variation in the expression of $\mathrm{AKT} / \mathrm{PKB}$ protein together with the expression of GLUT4 and IR proteins. The GnIH-induced changes in GLUT4 levels showed no significant correlation with the changes in AKT/PKB levels, but correlated significantly with the changes in IR protein. Furthermore, the insulin-induced changes in GLUT4 and IR levels correlated significantly with the changes in AKT/PKB levels in the adipose tissue. Although AKT/ $\mathrm{PKB}$ is involved in many signaling pathways including glucose trafficking (58), this finding suggests that AKT/PKB may function as a signaling molecule in the insulin-induced GLUT4 (59) and IR expression as well as in the GnIH-induced IR expression in the adipose tissue. But AKT/PKB may not function as a signaling molecule in the $\mathrm{GnIH}$-induced changes in the expression of GLUT4 protein in the adipose tissue.

In brief, the results of this study showed differential effect of $\mathrm{GnIH}$-induced changes in nutrient levels of the adipose tissue and testis of mice. The in vivo treatment with $\mathrm{GnIH}$ showed the increased expression of GLUT4 together with increased uptake of TGs in the adipose tissue, which in turn resulted in the increased accumulation of fat into WAT and increase in the body mass. On the contrary in the testis, GnIH treatment in vivo caused downregulation of GLUT8 expression resulting in the decreased uptake of glucose, which in turn resulted in the decreased synthesis of testosterone. The mice treated with $\mathrm{GnIH}$ also showed the decreased expression of IR protein in the testis. The decreased level of IR may be responsible for the decreased testicular activity in the mice. The in vitro treatment of $\mathrm{GnIH}$ to the adipose tissue showed the increased expression of GLUT4 suggesting the increased uptake of glucose, despite decrease in IR. The in vitro treatment of GnIH to the testis showed decreased expression of GLUT8 protein resulted in decreased uptake of glucose and testosterone synthesis. These findings thus suggest that $\mathrm{GnIH}$ increases nutrients (glucose and TGs) uptake in the adipose tissue resulted in accumulation of fat, whereas in the testis $\mathrm{GnIH}$ suppresses the glucose uptake resulted in the decreased testosterone synthesis in mice. This study further showed that the insulin-induced upregulation of GLUT4 expression may be PKB/AKT mediated, whereas $\mathrm{GnIH}$-induced upregulation of GLUT4 is not mediated through $\mathrm{PKB} / \mathrm{AKT}$ mechanisms. On the basis of present study, $\mathrm{GnIH}$ appears to serve an important role in determining the level of fat accumulation in the adipose tissue and accordingly modulating the reproductive strategies to be adopted by the animal. Further studies are required to find out whether the $\mathrm{GnIH}$ is associated with decline in testosterone as observed during diabetes mellitus type II, aging, or subfertility in men.

\section{AUTHOR CONTRIBUTIONS}

SA executed experimental design and analyze the result and manuscript preparation, AK analyze the result and edited the manuscript, and KT edited the whole manuscript with important suggestions.

\section{ACKNOWLEDGMENTS}

This work was supported in part by grant-in-aid from DST, New Delhi and CSIR, New Delhi to AK and SA highly acknowledges the financial assistance from the RFSMS-BSR-UGC, New Delhi.

\section{FUNDING}

Grant supported by University Grant Commission (UGC) New Delhi, India [F. 34-420/2008(SR), 2 January 2009] and Research Fellowship in Science for Meritorious Student-Basic Science Research- University Grant Commission (RFSMS-BSR-UGC), New Delhi, India [F.5-107/2007 (BSR)]. 


\section{REFERENCES}

1. Boland MP, Lonergan P, O'Callaghan D. Effect of nutrition on endocrine parameters, ovarian physiology, and oocyte and embryo development. Theriogenology (2001) 55:1323-40. doi:10.1016/S0093-691X(01)00485-X

2. Armstrong DG, Gong JG, Webb R. Interactions between nutrition and ovarian activity in cattle: physiological, cellular and molecular mechanisms. Reproduction (2003) 61:403-14.

3. Scaramuzzi RJ, Campbell BK, Downing JA, Kendall NR, Khalid M, MuñozGutiérrez M, et al. A review of the effects of supplementary nutrition in the ewe on the concentrations of reproductive and metabolic hormones and the mechanisms that regulate folliculogenesis and ovulation rate. Reprod Nutr Dev (2006) 46:339-54. doi:10.1051/rnd:2006016

4. Evans JJ, Anderson GM. Balancing ovulation and anovulation: integration of the reproductive and energy balance axes by neuropeptides. Hum Reprod Update (2012) 18:313-32. doi:10.1093/humupd/dms004

5. Yelich JV, Wettemann RP, Marston TT, Spicer LJ. Luteinizing hormone, growth hormone, insulin-like growth factor-I, insulin and metabolites before puberty in heifers fed to gain at two rates. Domes Anim Endocrinol (1996) 13:325-38. doi:10.1016/0739-7240(96)00046-X

6. Harris VM, Bendre SV, De Los Santos FG, Fite A, El-Dandachli AY, Kurenbekova L, et al. GnRH increases glucose transporter-1 expression and stimulates glucose uptake in the gonadotroph. JEndocrinol (2012) 212:139-47. doi:10.1530/JOE-11-0359

7. Simpson IA, Dwyer D, Malide D, Moley KH, Travis A, Vannucci SJ. The facilitative glucose transporter GLUT3: 20 years of distinction. Am J Physiol Endocrinol Metab (2008) 295:242-53. doi:10.1152/ajpendo.90388.2008

8. Purcell SH, Moley KH. Glucose transporters in gametes and preimplantation embryos. Trends Endocrinol Metab (2009) 20:483-9. doi:10.1016/j. tem.2009.06.006

9. Wang Q, Chi MM, Schedl T, Moley KH. An intercellular pathway for glucose transport into mouse oocytes. Am J Physiol Endocrinol Metab (2012) 302:E1511-8. doi:10.1152/ajpendo.00016.2012

10. Bucholtz DC, Vidwans NM, Herbosa CG, Schillo KK, Foster DL. Metabolic interfaces between growth and reproduction. V. Pulsatile luteinizing hormone secretion is dependent on glucose availability. Endocrinology (1996) 137:601-7. doi:10.1210/en.137.2.601

11. Crown A, Clifton DK, Steiner RA. Neuropeptide signaling in the integration of metabolism and reproduction. Neuroendocrinology (2007) 86:175-82. doi:10.1159/000109095

12. Schwartz MW, Figlewicz DP, Baskin DG, Woods SC, Porte D. Insulin in the brain: a hormonal regulator of energy balance. Endocrine Rev (1992) 13:387-414. doi:10.1210/er.13.3.387

13. Conway GS, Jacobs HS. Clinical implications of hyperinsulinaemia in women. Clin Endocrinol (1993) 39:623-32. doi:10.1111/j.1365-2265.1993.tb02419.x

14. Mueller WM, Gregoire FM, Stanhope KL, Mobbs CV, Mizuno TM, Warden $\mathrm{CH}$, et al. Evidence that glucose metabolism regulates leptin secretion from cultured rat adipocytes. Endocrinology (1998) 139:551-8. doi:10.1210/ endo.139.2.5716

15. Rato L, Alves MG, Socorro S, Duarte AI, Cavaco JE, Pedro F. Metabolic regulation is important for spermatogenesis. Nat Rev Urol (2012) 9:330-8. doi:10.1038/nrurol.2012.77

16. Banerjee A, Anuradha, Mukherjee K, Krishna A. Testicular glucose and its transporter GLUT 8 as a marker of age-dependent variation and its role in steroidogenesis in mice. J Exp Zool A Ecol Genet Physiol (2014) 321:490-502. doi:10.1002/jez.1881

17. Galardo MN, Riera MF, Pellizzari EH, Chemes HE, Venara MC, Cigorraga SB, et al. Regulation of expression of Sertoli cell glucose transporters 1 and 3 by FSH, IL1 $\beta$, and bFGF at two different time-points in pubertal development. Cell Tissue Res (2008) 334:295-304. doi:10.1007/s00441-008-0656-y

18. Doege H, Schurmann A, Bahrenberg G, Brauers A, Joost HG. GLUT8, a novel member of the sugar transport facilitator family with glucose transport activity. J Biol Chem (2000) 275:16275-80. doi:10.1074/jbc.275.21.16275

19. Vannelli BG, Barni T, Orlando C, Natali A, Serio M, Balboni GC. Insulin like growth factor-I (IGF-I) and IGF-I receptor in human testis: an immunohistochemical study. Fertil Steril (1988) 49:666-9.

20. Nakae J, Kido Y, Accili D. Distinct and overlapping functions of insulin and IGF-I receptors. Endocrine Rev (2001) 22:818-35. doi:10.1210/edrv.22.6.0452
21. Kim JJ, Accili D. Signalling through IGF-I and insulin receptors: where is the specificity? Growth Horm IGF Res (2002) 12:84-90. doi:10.1054/ ghir.2002.0265

22. Stewart T, Baker G. Inverse relationship between obesity and testicular function. Obesity (2008) 10:34-6.

23. Mah PM, Wittert GM. Obesity and testicular function. Mol Cell Endocrinol (2010) 316:180-6. doi:10.1016/j.mce.2009.06.007

24. Acosta-Martinez M. PI3K: an attractive candidate for the central integration of metabolism and reproduction. Front Endocrinol (2011) 2:110. doi:10.3389/ fendo.2011.00110

25. Clarke IJ, Smith JT, Henry BA, Oldfield BJ, Stefanidis A, Millar RP, et al. Gonadotropin-inhibitory hormone is a hypothalamic peptide that provides a molecular switch between reproduction and feeding. Neuroendocrinology (2012) 95:305-16. doi:10.1159/000332822

26. Tsutsui K, Saigoh E, Ukena K, Teranishi H, Fujisawa Y, Kikuchi M, et al. A novel avian hypothalamic peptide inhibiting gonadotropin release. Biochem Biophys Res Commun (2000) 275:661-7. doi:10.1006/ bbrc. 2000.3350

27. Tsutsui K. Review: a new key neurohormone controlling reproduction, gonadotropin-inhibitory hormone $(\mathrm{GnIH})$ : biosynthesis, mode of action and functional significance. Prog Neurobiol (2009) 88:76-88. doi:10.1016/j. pneurobio.2009.02.003

28. Tsutsui K, Bentley GE, Bedecarrats GT, Osugi T, Ubuka T, Kriegsfeld LJ. Review: gonadotropin-inhibitory hormone $(\mathrm{GnIH})$ and its control of central and peripheral reproductive function. Front Neuroendocrinol (2010) 31:284-95. doi:10.1016/j.yfrne.2010.03.001

29. Tsutsui K, Ubuka T, Bentley GE, Kriegsfeld LJ. Review: gonadotropin-inhibitory hormone $(\mathrm{GnIH})$ : discovery, progress and prospect. Gen Comp Endocrinol (2012) 177:305-14. doi:10.1016/j.ygcen.2012.02.013

30. Sam AH, Dhillo WS. Endocrine links between fat and reproduction. Obst Gynaecol (2010) 12(4):231-6.

31. Anjum S, Krishna A, Tsutsui K. Inhibitory roles of the mammalian GnIH ortholog RFRP-3 in testicular activities in adult mice. J Endocrinol (2014) 223:1-14. doi:10.1530/JOE-14-0333

32. Tachibana T, Masuda N, Tsutsui K, Ukena K, Ueda H. The orexigenic effect of GnIH is mediated by central opioid receptors in chicks. Comp Biochem Physiol A Mol Integ Physiol (2008) 150:21-5. doi:10.1016/j.cbpa.2008.02.018

33. Johnson MA, Tsutsui K, Fraley GS. Rat RFamide-related peptide-3 stimulates GH secretion, inhibits LH secretion, and has variable effects on sex behavior in the adult male rat. Horm Behav (2007) 51:171-80. doi:10.1016/j. yhbeh.2006.09.009

34. Son YL, Ubuka T, Millar RP, Kanasaki H, Tsutsui K. Gonadotropin-inhibitory hormone inhibits GnRH-induced gonadotropin subunit gene transcriptions by inhibiting AC/cAMP/PKA-dependent ERK pathway in L $\beta$ T2 cells. Endocrinology (2012) 153:2332-43. doi:10.1210/en.2011-1904

35. Anjum S, Krishna A, Sridaran R, Tsutsui K. Localization of GonadotropinReleasing Hormone (GnRH), Gonadotropin-Inhibitory Hormone (GnIH), Kisspeptin and GnRH-Receptor and their possible roles in testicular activities from birth to senescence in mice. J Exp Zool (2012) 317A:630-44. doi:10.1002/ jez.1765

36. Singh P, Krishna A, Tsutsui K. Effects of gonadotropin inhibitory hormone on folliculogenesis and steroidogenesis of cyclic mice Fertil. Steril (2011) 95(4):1397-404. doi:10.1016/j.fertnstert.2010.03.052

37. Singh P, Krishna A. Effects of GnRH agonist treatment on steroidogenesis and foliculogenesis in the ovary of cyclic mice. J Ovarian Res (2010) 3:26. doi:10.1186/1757-2215-3-26

38. Roy VK, Krishna A. Regulation of leptin synthesis during adipogenesis in males of a vespertilionid bat, Scotophilus heathi. J Exp Biol (2011) 214:1599606. doi: $10.1242 / \mathrm{jeb} .054973$

39. Lowry OH, Rosebrough NJ, Farr AL, Randall RJ. Protein measurement with the folin phenol reagent. J Biol Chem (1951) 193:265-75.

40. Cifuentes M, Albala C, Cecilia Rojas C. Calcium-sensing receptor expression in human adipocytes. Endocrinology (2005) 146:2176-9. doi:10.1210/ en.2004-1281

41. Paglialunga S, Schrauwen P, Roy C, Moonen-Kornips E, Lu H, Hesselink MKC, et al. Reduced adipose tissue triglyceride synthesis and increased muscle fatty acid oxidation in C5L2 knockout mice. J Endocrinol (2007) 194:293-304. doi:10.1677/JOE-07-0205 
42. Lee Y, Hirose H, Ohneda M, Johnson JH, McGarry JD, Unger RH. Beta-cell lipotoxicity in the pathogenesis of non-insulin-dependent diabetes mellitus of obese rats: impairment in adipocyte-beta cell relationships. Proc Natl Acad Sci U S A (1994) 91:10878-82. doi:10.1073/pnas.91.23.10878

43. Murakami M, Matsuzaki T, Iwasa T, Irahara M, Osugi T, Tsutsui K. Hypophysiotropic role of RFamide-related peptide-3 in the inhibition of LH secretion in female rats. J Endocrinol (2008) 19:105-12. doi:10.1677/ JOE-08-0197

44. van Harmelen V, Dicker A, Sjolin E, Blomqvist L, Wirén M, Hoffstedt J, et al. Effects of pain controlling neuropeptides on human fat cell lipolysis. Int J Obesity (2010) 34:1333-40. doi:10.1038/ijo.2010.46

45. Valassi E, Scacchi M, Cavagnini F. Neuroendocrine control of food intake. Nutri Metab Cardiovasc Dis (2008) 18:158-68. doi:10.1016/j. numecd.2007.06.004

46. Clarke IJ, Qi Y, Sari IP, Smith JT. Review: evidence that RF-amide related peptides are inhibitors of reproduction in mammals. Front Neuroendocrinol (2009) 30:371-8. doi:10.1016/j.yfrne.2009.04.001

47. Sridaran R, Krishna A, Srivastava RK. Effects of Long-Term Treatment of a GnRH Agonist on Ovarian Function in the Rat. Signaling Mechanisms and Gene Expression in the Ovary. New York: Springer-Verlag New York, Inc. Serono Symposia USA (1991). p. 391-4.

48. Clark JT, Kalra PS, Crowley WR, Kalra SP. NPY and human pancreatic polypeptide stimulate feeding behavior in rats. Endocrinology (1984) 115:427-9. doi:10.1210/endo-115-1-427

49. Furtado LM, Somwar R, Sweeney G, Niu W, Klip A. Activation of the glucose transporter GLUT4 by insulin. Biochem Cell Biol (2002) 80:569-78. doi:10.1139/o02-156

50. Kouidhi S, Berrhouma R, Rouissi K, Jarboui S, Clerget-Froidevaux MS, Seugnet I, et al. Human subcutaneous adipose tissue Glut 4 mRNA expression in obesity and type 2 diabetes. Acta Diabetol (2013) 50:227-32. doi:10.1007/ s00592-011-0295-8

51. Lacombe VA. Expression and regulation of facilitative glucose transporters in equine insulin-sensitive tissue: from physiology to pathology. ISRN Vet Sci (2014) 409547:15. doi:10.1155/2014/409547

52. Aerni-Flessner L, Abi-Jaoude M, Koenig A, Payne M, Hruz PW. GLUT4, GLUT1, and GLUT8 are the dominant GLUT transcripts expressed in the murine left ventricle. Cardiovasc Diabetolo (2012) 11:63. doi:10.1186/1475-2840-11-63

53. Carayannopoulos MO, Chi MM, Cui Y, Pingsterhaus JM, McKNight RA, Mueckler M, et al. GLUT8 is a glucose transporter responsible for insulin-stimulated glucose uptake in the blastocyst. Proc Natl Acad Sci U S A (2000) 97:7313-8. doi:10.1073/pnas.97.13.7313

54. Zhao S, Zhu E, Yang C. RFamide-related peptide and messenger ribonucleic acid expression in mammalian testis: association with the spermatogenic cycle. Endocrinology (2010) 151:617-27. doi:10.1210/en.2009-0978

55. Bajpai M, Gupta G, Setty BS. Changes in carbohydrate metabolism of testicular germ cells during meiosis in the rat. Europ J Endocrinol (1998) 138:322-7. doi:10.1530/eje.0.1380322

56. Ahn SW, Gang GT, Kim YD, Ahn RS, Harris RA, Lee CH, et al. Insulin directly regulates steroidogenesis via induction of the orphan nuclear receptor DAX-1 in testicular Leydig cells. J Biol Chem (2013) 288:15937-46. doi:10.1074/jbc. M113.451773

57. Rommerts FFG, Van Doom LC, Caljaard H, Cooke BA, Van Der Molen HJ. Dissection of wet tissue and freeze-dried sections in the investigation of seminiferous tubules and interstitial tissue from rat testis. J Histochem Cytochem (1973) 21:572-9. doi:10.1177/21.6.572

58. Hajduch E, Litherland GJ, Hundal HS. Protein kinase B (PKB / Akt) - a key regulator of glucose transport? FEBS Lett (2001) 492:199-203. doi:10.1016/ S0014-5793(01)02242-6

59. Huang S, Czech MP. The GLUT4 glucose transporter. Cell Metab (2007) 5(4):237-52. doi:10.1016/j.cmet.2007.03.006

Conflict of Interest Statement: The authors declare that the research was conducted in the absence of any commercial or financial relationships that could be construed as a potential conflict of interest.

Copyright (c) 2016 Anjum, Krishna and Tsutsui. This is an open-access article distributed under the terms of the Creative Commons Attribution License (CC BY). The use, distribution or reproduction in other forums is permitted, provided the original author(s) or licensor are credited and that the original publication in this journal is cited, in accordance with accepted academic practice. No use, distribution or reproduction is permitted which does not comply with these terms. 